\title{
Workshop Lesson Plan dan Lembar Observasi untuk Meningkatkan Kompetensi Guru IPA SMP dalam Merencanakan Pembelajaran
}

\author{
Wahyudi $^{1}$, Dwi Fajar Saputri ${ }^{2}$, Sri Koriaty $^{3}$, Nurhayati ${ }^{4}$ \\ ${ }^{1,2,4}$ Program Studi Pendidikan Fisika, Fakultas P. MIPA dan Teknologi, IKIP PGRI Pontianak \\ ${ }^{3}$ Program Studi Pendidikan Teknologi Informasi dan Komputer, Fakultas P. MIPA dan Teknologi, \\ IKIP PGRI Pontianak \\ wahyudi.kakap@gmail.com
}

\begin{abstract}
ABSTRAK
Guru-guru masih mengalami kesulitan dalam menyampaikan materi IPA. Dalam proses pembelajaran guru masih hanya terfokus pada penyampaian materi tanpa memperhatikan apakah siswa benar-benar belajar atau tidak. Solusi dari permasalahan yang dialami guru-guru yaitu dengan melaksanakan pelatihan dan pendampingan untuk meningkatkan kompetensi guru dalam merencanakan pembelajaran dengan menyusun lesson plan dan lembar observasi. Metode pengabdian yang dilaksanakan berupa pelatihan dan workshop. Tahap kegiatan meliputi perencanan, pelaksanaan dan evaluasi. Sasaran kegiatan adalah guru IPA yang tergabung dalam MGMP IPA SMP di Kabupaten Kubu Raya. Hasil kegiatan menunjukkan bahwa guru antusias menghadiri kegiatan pelatihan. Guru dapat merancang lesson plan dan lembar observasi serta menentukan media yang akan digunakan dalam implementasi lesson study. Pemahaman guru tentang perencanaan pembelajaran juga meningkat setelah dilakukan kegiatan pelatihan.
\end{abstract}

Kata kunci: Lesson plan, Lesson study, Pembelajaran IPA

\begin{abstract}
Teachers still experience difficulties in delivering science materials. In the learning process the teacher is still only focused on the delivery of material without regard to whether students really learn or not. The solution to the problems experienced by teachers is by conducting training and mentoring to improve teacher competence in planning learning by preparing lesson plans and observation sheets. Implementation methode of community engagment activity was training and workshops. The activity included planning, implementing and evaluating. The subject of activity was the science teacher who is a member of the MGMP IPA SMP in Kubu Raya Regency. The results of community engagment activity showed that the teacher was enthusiastic in attending the training activities. The teacher can design lesson plans and observation sheets and determine the media that will be used in the implementation of lesson study. Teachers' understanding of learning planning was increase after the training activities.
\end{abstract}

Keywords: Lesson plan, Lesson study, Science Learning

\section{PENDAHULUAN}

Kabupaten Kubu Raya merupakan salah satu kabupaten yang ada di Provinsi Kalimantan Barat. Kabupaten Kubu Raya yang diresmikan tanggal 17 Juli 2007 memiliki 9 kecamatan yang berada di beberapa pulau perairan dengan total luas wilayah $6.958 \mathrm{~km} 2$. Berdasarkan pusat data referensi kementerian pendidikan dan kebudayaan jumlah Sekolah Mengah Pertama (SMP dan MTs) yang berada dibawah naungan Dinas Pendidikan Kabupaten Kubu Raya sebanyak 486 sekolah dengan jumlah guru sebanyak 1.414 orang. SMP tersebut juga tersebar di berbagai kecamatan baik yang berada di daratan pulau besar maupun di daerah pulau-pulau kecil di perairan tepi Kalimantan Barat.

Faktor geografis tersebut menjadikan para guru khususnya Sekolah Menengah Pertama masih kesulitan mengikuti berbagai kegiatan pengembangan kompetensi dan mendapatkan akses informasi pendidikan.

Musyawarah Guru Mata Pelajaran (MGMP) merupakan forum diskusi bagi guru mata pelajaran dalam berbagi informasi dalam meningkatkan kompetensi terutama 
kompetensi pedagogik. Satu diantara MGMP yang aktif di kabupaten Kubu Raya yaitu MGMP IPA beranggotakan guru SMP yang berasal dari berbagai kecamatan di Kabupaten Kubu Raya. Berbagai bentuk kegiatan dilakukan oleh guru yang tergabung dalam MGMP IPA guna berdiskusi dan mencari solusi terhadap permasalahan yang timbul dalam kegiatan belajar mengajar di sekolah khususnya dalam pembelajaran IPA.

$$
\text { Berdasarkan wawancara yang }
$$

dilakukan tim PKM dengan ketua MGMP IPA Kabupaten Kubu Raya diperoleh informasi bahwa guru-guru masih mengalami kesulitan dalam menyampaikan materi IPA. Informasi yang diperoleh bahwa guru-guru dalam pembelajaran masih terfokus pada penyampaian materi tanpa memperhatikan apakah siswa benar-benar belajar atau tidak. Guru-guru beranggapan bahwa jika materi telah tersampaikan dan diakhir pembelajaran siswa tidak ada bertanya maka pembelajaran dikatakan telah sesuai dengan rencana (harapan). Namun berdasarkan hasil tes yang diberikan kepada siswa, diketahui bahwa masih banyak siswa yang memiliki nilai di bawah kriteria yang ditetapkan sekolah.

Infromasi lain yang diperoleh dari MGMP yaitu para guru juga kesulitan melakukan observasi pembelajaran saat menyampaikan materi di depan kelas. Menurut Mania (2008), observasi dalam kegiatan pengajaran sangat bermanfaat karena dapat digunakan untuk mengukur dan menilai proses belajar seperti aktivitas siswa mengikuti kegiatan belajar, kegiatan diskusi, partisipasi dalam simulasi dan aktivitas belajar lainnya serta juga dapat digunakan untuk mengukur hasil belajar siswa. Namun, pelaksanaan observasi di kelas tidak dapat dilakukan secara maksimal jika guru yang mengajar di kelas juga dibebankan sebagai observer seperti. Kesulitan tersebut yang dirasakan oleh para guru MGMP IPA SMP Kabupaten Kubu Raya, karena pembelajaran jarang sekali dilakukan dengan cara berkolaborasi bersama guru lain. Untuk melakukan mengamati aktivitas belajar siswa di kelas dibutuhkan beberapa orang observer yang dapat mengamati aktivitas siswa dalam belajar di kelas. Observer juga diharapkan dapat memberikan saran dan masukkan terhadap keterlaksanaan proses pembelajaran di kelas.

Penerapan Kurikulum 2013 telah dilakukan oleh sekolah-sekolah menengah pertama di Kabupaten Kubu Raya. Namun, berdasarkan diskusi dengan Ketua MGMP IPA
Kabupaten Kubu Raya diketahui bahwa para guru IPA memiliki keluhan dalam mengimplementasikan pendekatan saintifik yng merupakan karakteristik dalam Kurikulum 2013 (Hosnan, 2014). Rencana pembelajaran disusun sebagian hanya bersifat formalitas dan kebanyakan mengadopsi dari berbagai sumber tanpa adanya penyesuaian dengan lingkungan dan kondisi di dalam kelas. Lebih lanjut, dalam diskusi dengan Ketua MGMP IPA diperoleh informasi bahwa pembelajaran yang dilaksanakan guru hanya sebatas menekankan pada kemampuan mengamati (observing) dan menanya (questioning). Guru kesulitan dalam mengembangkan keterampilan lainnya seperti memprediksi (predicting), bereksperimen (experimenting), menyimpulkan (inferring), hingga mengintepretasikan (intepreting) yang merupakan keterampilan proses penyelidikan dalam pendekatan saintifik (Bertsch, Kapelari \& Unterbruner, 2014). Langkah-langkah saintifik dalam rencana pembelajaran yang dibuat juga belum disesuaikan dengan sumber dan media belajar yang dimiliki oleh guru. Sehingga guru dalam melaksanakan pembelajaran seringkali tidak lagi berpedoman pada rencana pembelajaran berbasisi saintifik yang telah dibuat.

Berdasarkan beberapa permasalahan yang dialami oleh para guru MGMP IPA SMP Kabupaten Kubu Raya di atas, maka Tim Dosen IKIP PGRI Pontianak berinisiasi melaksanakan kegiatan Pengabdian pada Masyarakat.

Kegiatan Pengabdian dilaksanakan dalam bentuk pelatihan penyusunan lesson plan serbasis pendekatan saintifik. Solusi tersebut dilakukan dengan tujuan agar para guru IPA mampu menyusun sebuah rencana pembelajaran kolaboratif dengan mengintegrasikan pendekatan saintifik serta nantinya diimplementasikan dalam bentuk lesson study.

Lesson study bukanlah suatu metode mengajar melainkan suatu model pembinaan profesi guru melalui belajar mengajar (pengkajian pembelajaran) secara kolaboratif dengan sistem siklus yang berkelanjutan serta berlandaskan prinsip-prinsip kolegalitas dan mutual learning untuk membangun learning community (Subadi \& Hidayati, 2013). Dalam melaksanakan lesson study guru dapat menggunakan model pembelajaran berbasis saintifik seperti model inquiry based learning, model discovery learning, model problem based learning dan model saintifik lainnya. Fakta empirik dari berbagai hasil penelitian 
menunjukkan bahwa lesson study dapat meningkatkan produktivitas guru dalam melaksanakan pembelajaran serta berdampak pada proses dan hasil belajar siswa yang menjadi lebih baik. Melalui lesson study, guru dapat mempersiapkan perangkat pembelajaran dengan baik, mengimplementasikan pembelajaran dan memperoleh berbagai masukkan dari kegiatan refleksi untuk terus memperbaiki proses pembelajaran yang dilaksanakan (Murtiani, dkk, 2012).

$$
\text { Dalam pembelajaran IPA, }
$$

implementasi lesson study terbukti dapat meningkatkan keterampilan kerja ilmiah siswa dan hasil belajar siswa secara efektif (Rahayu, 2012) dan dapat meningkatkan kemampuan pemecahan masalah bagi siswa (Mustofa, 2016). Kompetensi profesional, pedagogik, kepribadian dan sosial guru IPA dapat meningkat setelah melaksanakan lesson study (Winarsih \& Mulyani, 2012). Untuk menerapkan lesson study, para guru perlu diberikan pemahaman tentang cara melaksanakan lesson study mulai dari merencanakan (plan), melaksanakan (do) dan merefleksi (see). Dalam tahapan perencanaan para guru dilatihkan untuk melakukan analisis kebutuhan pembelajaran dan penyusunan lesson plan berbasis saintifik seperti yang telah dilakukan dalam program pengabdian masyarakat ini. Selain itu, dalam kegiatan ini para guru juga dibimbing dalam menyusun perangkat pembelajaran berupa lembar observasi yang akan digunakan untuk pengamatan dalam proses pembelajaran.

\section{METODE PENELITIAN}

Metode kegiatan pengabdian pada masyarakat ini dilaksanakan melalui Pelatihan kepada guru-guru dalam menyusun lesson plan dan perangkat pembelajaran berupa lembar observasi sebagai tahap perencanaan lesson study. Sasaran kegiatan adalah seluruh Guru IPA SMP/MTs di Kabupaten Kubu Raya yang tergabung dalam MGMP IPA SMP Kabupaten Kubu Raya. Tahapan kegiatan pengabdian yang dilakukan meliputi tahapan persiapan, pelaksanaan dan evaluasi sebagai berikut;

\section{Tahapan Persiapan}

Persiapan pelatihan diawali dengan diskusi persiapan antara Tim Pengabdian dengan Ketua MGMP IPA SMP Kabupaten Kubu Raya untuk menggali informasi mengenai berbagai kesulitan guru dalam menyusun rencana pembelajaran dan penentuan waktu pelatihan dan lokasi strategis untuk pelaksanaan pelatihan. Persiapan selanjutnya adalah penyusunan materi pelatihan tentang implementasi lesson study dan teknik penysunan lesson plan serta pedoman observasi Kemudian disusun modul pelatihan penyusunan lesson plan dan lembar observasi yang akan diberikan kepada guru saat pelatihan.

Penyiapan bahan-bahan peralatan tulis juga dilakukan guna kelancaran dalam penyusunan lesson plan dan lebar observasi saat sesi pelatihan.

\section{Tahapan Pelaksanaan Pelatihan.}

Pelaksanaan pelatihan diawali dengan tes awal (pre-test) dalam bentuk tes tertulis untuk mengetahui pemahaman guru tentang perencanaan pembelajaran yang meliputi Tahapan penyusunan rencana pembelajaran, prinsip penyusunan rencanan pembelajaran, pengembangan indikator pembelajaran dan esensi langkah-langkah pembelajaran dalam rencana pembelajaran. Kemudian, pelaksanaan pelatihan di lakukan melalui dua sesi. Sesi pertama adalah penyampaian materi tentang pengenalan lesson study dan gambaran praktek lesson study di negara asalnya yakni Jepang. Penyampaian materi dilakukan dengan menggunakan metode ceramah atau presentasi dengan menampilkan materi dan berbagai video tentang praktek lesson study.

Materi sesi pertama ini selain disampaiakn oleh Tim Pengabdi juga disampaikan oleh Tim Lesson study Club Kalimantan Barat (LSC-KB) yang pernah berkunjung dan mempraktekkan lesson study di Jepang. Metode tanya jawab juga digunakan dalam penyampaian materi pelatihan agar peserta lebih mendalami materi pelatihan.

Sesi kedua dalam pelaksanaan pelatihan dilakukan dengan metode praktek. Para guru secara berkelompok dibimbing untuk membuat lesson plan dan lembar observasi pelajaran IPA meliputi fisika dan biologi masing-masing sebanyak tiga rencana pertemuan pembelajaran dan kimia sebanyak dua rencana pertemuan pembelajaran. Diakhir sesi ini dilakukan presentasi pemaparan lesson plan dan lembar observasi yang telah dibuat masing-masing kelompok serta masukkan dari peserta terhadap lesson plan yang telah dibuat.

\section{Tahapan Evaluasi Pelatihan}

Pada tahapan ini dilakukan evaluasi dengan merangkum seluruh masukkan dari desain lesson plan dan lembar observasi yang telah dibuat. Rencana tindak lanjut hasil pelatihan juga dilakukan menentukan jadwal waktu dan lokasi open class serta penetapan 
guru model pelaksana open class pada masing masing kelompok. Diakhir pelatihan para guru diberikan tes akhir (post-test) untuk mengukur peningkatan pemahaman guru tentang lesson study dan perangkat pembelajaran. Tes diberikan dalam bentuk tes tertulis.

Indikator keberhasilan kegiatan pengabdian pada masyarakat melaui Program Kemitraan Masyarakat (PKM) ini adalah: 1) Kehadiran atau antusias, minimal $80 \%$ dari dari 52 guru IPA SMP Kabupaten Kubu Raya yang aktif dan diundang dapat menghadiri pelatihan, 2) Tingkat Pemahaman, adanya peningkatan pemahaman guru tentang implementasi lesson study dalam pembelajaran IPA setelah mengukuti pelatihan dan 3) Setiap guru/kelompok guru dapat menyusun lesson plan dan lembar observasi mata pelajaran IPA setelah mengikuti pelatihan.

\section{HASIL \& PEMBAHASAN}

\section{Tahap Persiapan Pelatihan}

Sebelum dilaksanakannya kegiatan pelatihan dan workshop, Tim Pengabdi melakukan persiapan dengan melakukan diskusi persiapan dengan Ketua MGMP IPA SMP Kabupaten Kubu Raya (Gambar 1). Kegiatan diskusi dilakukan untuk menggali informasi mengenai berbagai kesulitan guru dalam menyusun rencana pembelajaran dan penentuan waktu pelatihan dan lokasi strategis untuk pelaksanaan pelatihan.

Hasil diskusi disimpulkan bahwa pembelajaran dirancang dalam bentuk lesson study sehingga diperlukan sebuah lesson plan dan perangkat pembelajaan berupa lembar observasi guna menunjang penerapan lesson study. Hasil diskusi juga dihasilkan kesepakatan jadwal pelaksanaan kegiatan yaitu pada tanggal 04 April 2019 di SMPN 01 Rasau Jaya. Kemudian dalam tahap persiapan selanjutnya, Tim pengabdi menyusun materi kegiatan serta kelengkapan pelatihan berupa modul pelatihan penyusunan lesson plan dan lembar observasi yang akan diberikan kepada guru saat pelatihan.

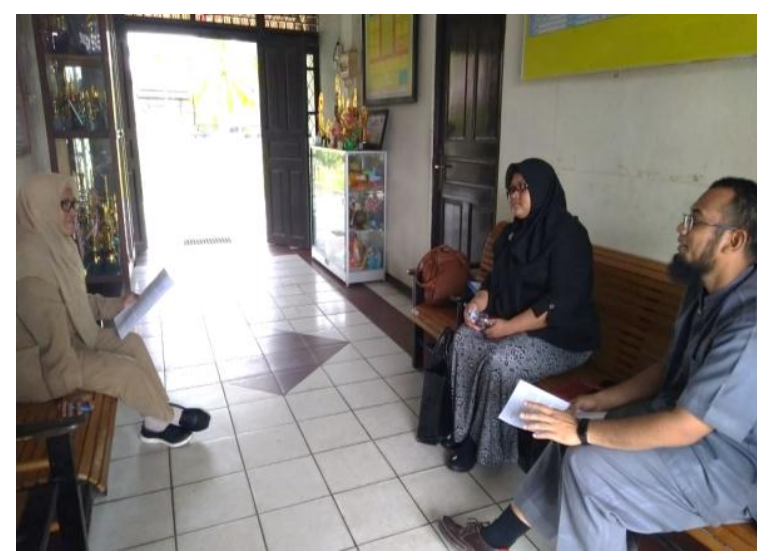

Gambar 1. Diskusi Tim PKM dengan Ketua MGMP IPA SMP Kabupaten Kubu Raya dalam merencanaan Kegiatan PKM

\section{Tahap Pelaksanaan Pelatihan}

Kegiatan workshop desain lesson plan dan perangkat pembelajaran IPA dilaksanakan pada tanggal 04 April 2019 di SMPN 01 Rasau Jaya Kabupaten Kubu Raya. Kegiatan workshop dihadiri oleh Pengawas dan Pembina Mata Pelajaran IPA SMP Kabupaten Kubu Raya yakni Bapak Widayaka, S.Pd yang sekaligus membuka acara wokshop (Gambar 2). Dalam sambutannya, Pengawas dan Pembina Mata Pelajaran IPA SMP Kabupaten Kubu Raya sangat mengapresiasi dan memberi dukungan atas pelaksanaan program yang dilaksanakan oleh Tim PKM yang bekerjasama dengan MGMP IPA SMP Kabupaten Kubu Raya. Kegiatan yang dilaksanakan oleh Tim PKM dipandang sebagai salah satu bentuk partisipasi perguruan tinggi melalui tenaga dosen dalam meningkatkan kualitas pendidikan dan pembelajaran khususnya pelajaran IPA SMP di Kabupaten Kubu Raya.

Sebelum kegiatan wokshop dimulai, peserta diberikan tes awal (pre-test). Tes yang diberikan dalam bentuk tes tertulis untuk mengetahui pemahaman awal guru mengenai Tahapan penyusunan rencana pembelajaran, prinsip penyusunan rencanan pembelajaran, pengembangan indikator pembelajaran dan esensi langkah-langkah pembelajaran dalam rencana pembelajaran. Peserta workshop antusias mengerjakan tes awal sampai tuntas namun dibatasi sesuai dengan waktu yang telah ditentukan. 


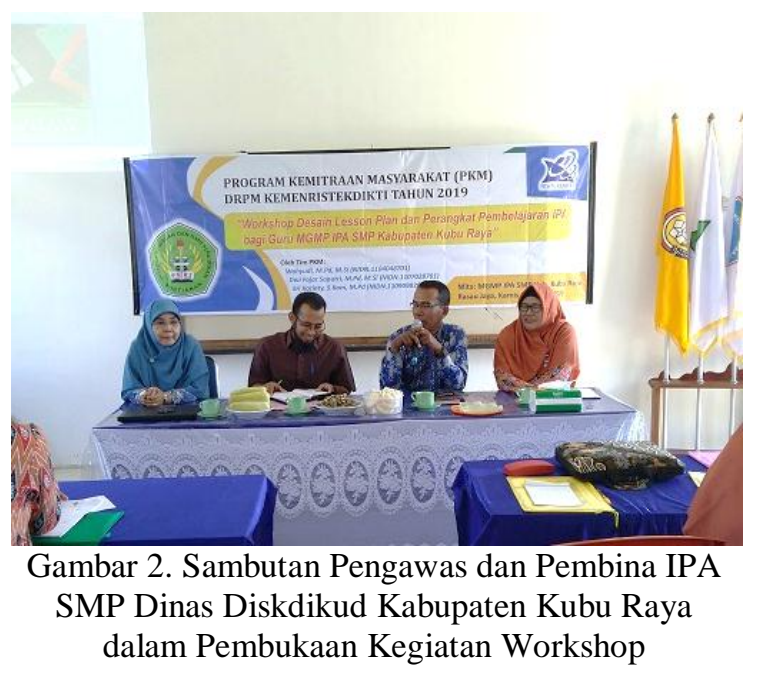

adalah pesi pertama kegiatan workshop pengenalan lesson study dan gambaran praktek lesson study di negara asalnya yakni Jepang. Penyampaian materi dilakukan dengan menggunakan metode ceramah atau presentasi dengan menampilkan materi dan berbagai video tentang praktek lesson study. Materi sesi pertama ini selain disampaiakn oleh Tim PKM (Gambar 3) juga disampaikan oleh Tim Lesson study for Learning Communyty Club Kalimantan Barat (LSLC-KB) (Gambar 4) yang pernah berkunjung dan mempraktekkan lesson study di Jepang.

Kegiatan PKM yang berfokus pada penerapan lesson study ini diarahkan untuk peningkatan kualitas pembelajaran IPA bagi guru IPA Kabupaten Kubu Raya yang tergabung dalam Musyawarah Guru Mata Pelajaran (MGMP) IPA.

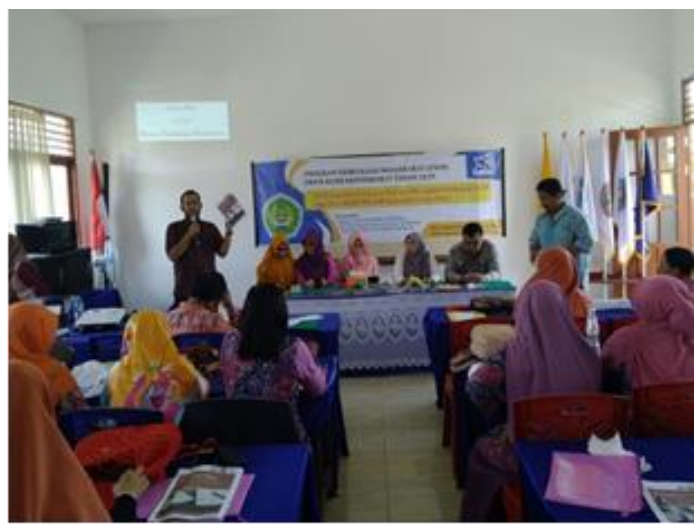

Gambar 3. Penyampaian Materi Lesson study oleh Tim PKM

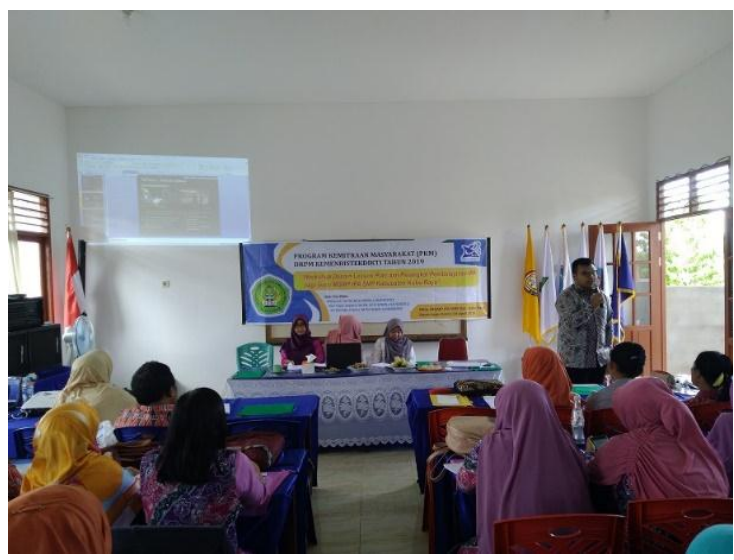

Gambar 4. Penyampaian Materi Praktek

Lesson study oleh Lesson study for Learning Community (LSLC) Kalimantan Barat

Pengembangan lesson study berbasis MGMP sudah dilakukan sejak tahun 20062008 melalui program Strenghthening InService Teacher Training of Mathematics and Science Education at Junior Secondary Level (SISTTEMS) bekerjasama dengan Depdiknas, Depag serta Japan Insternational Cooperation Agency (JICA) bertujuan meningkatkan mutu pendidikan di tingkat SMP dengan menata ulang dan mengaktifkan kembali kegiatan MGMP melalui kegiatan lesson study (Susilo, dkk, 2010). Namun bagi MGMP IPA SMP Kabupaten Kubu Raya, kegiatan ini merupakan kali pertama dilaksanakan melalui Program Kemitraan Masyarakat (PKM) Tim Pengabdi IKIP PGRI Pontianak.

Materi tentang lesson study memberikan banyak pengetahuan bagi para guru MGMP IPA tentang tujuan dan manfaat dari penerapan lesson study. Para guru juga mendapatkan pemahaman tentang langkahlangkah atau siklus dalam penerapan lesson study yang meliputi langkah plan (merencanakan atau merancang), langkah $d o$ (melaksanakan), langkah see (mengamati dan kemudian merefleksi hasil pengamatan). Pemaparan materi tentang lesson study memberikan pemahaman kepada guru bahwa kompetensi pedagogik seorang guru dapat ditingkatkan melalui usaha kolabiratif dan berkelanjutan dengan berlandaskan pada prinsip-prinsip kolegial dan mutual learning dalam komunitas belajar.

Sesi kedua kegiatan workshop adalah pembuatan lesson plan atau rencana pelaksanaan pembelajaran (RPP) dan perangkat pembelajaran berupa lembar observasi sebagai bagian dari tahapan plan (perencanaan) dalam lesson study. Pendampingan penyusunan lesson plan atau 
RPP didasarkan bahwa selama ini para guru masih kesulitan dalam menysun RPP yang sesuai dengan karakteristik materi dan karateristik peserta didik serta merancang pembelajaran yang merbasis saintifik.

Selama ini RPP yang digunakan oleh guru diperoleh dari mendownload dari internet dan tidak dapat diterapkan secara maksimal di kelas. Saito (2007) juga mengungkapkan bahwa penyusunan lesson plan atau RPP merupakan salah satu permasalahan dalam lesson study (Susilo, dkk, 2011). Dengan disusunnya RPP secara bersama maka seluruh guru merasa memiliki RPP yang disusun serta dapat memahami langkah demi langkah pembelajaran yang akan dilakukan.

Penyusunan lesson plan atau RPP diawali dengan membentuk kelompok guru menjadi 3 kelompok besar yaitu kelompok biologi, kelompok kimia dan kelompok fisika. Para guru dalam kelompok kemudian diarahkan untuk berdiskusi dalam menelaah kompetensi inti, standar kompetensi serta indikator yang akan dikembangkan ke dalam lesson plan (Gambar 5).

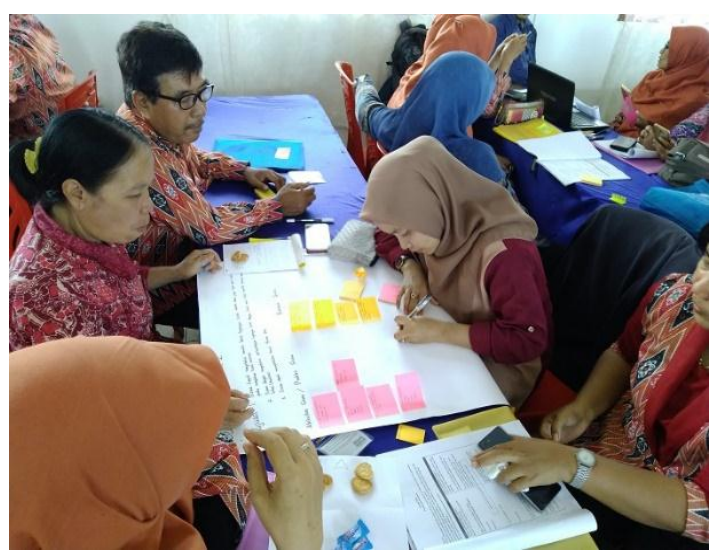

Gambar 5. Proses Penusunan lesson plan oleh Kelompok Guru

Selanjutnya para guru diarahkan dan dibimbing dalam merancang sintak atau langkah-langkah pembelajaran dengan menggunakan pendekatan saintifik serta menentukan media yang akan dirancang guna membantu proses pembelajaran saat mengimplementasikan pembelajaran.

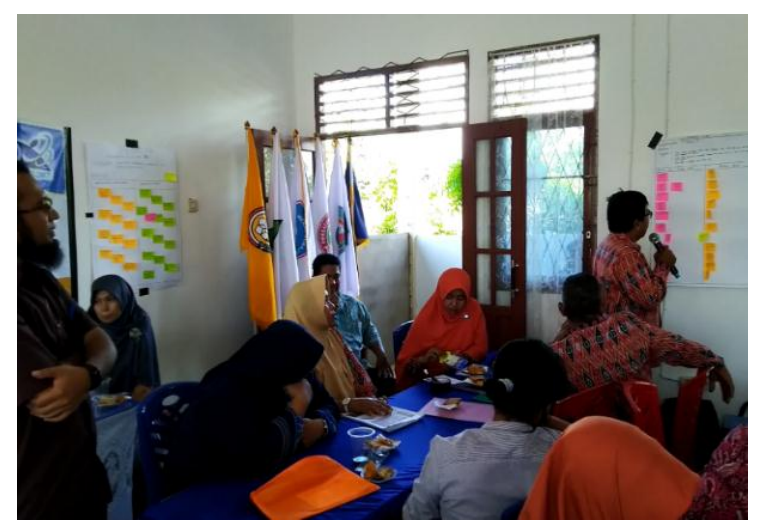

Gambar 6. Sesi Presentasi lesson plan yang Disusun oleh Guru

Lesson plan yang disusun oleh guru dalam kelompoknya tidak hanya didasarkan pada hasil diskusi dalam satu kelompok namun juga harus mendapatkan masukkan dari kelompok lainnya. Sehingga pada akhir sesi penysunan lesson plan, setiap kelompok mempresentasikan lesson plan yang telah disusun dan ditanggapi oleh kelompok lainnya (Gambar 6). Masukkan dan saran dari kelompok lain akan dijadikan koreksian untuk menyempurnakan lesson plan yang telah disusun. Kemudian diakhir presentasi kelompok dipilih kelompok yang paling baik untuk diberikan apresiasi dalam menysun lesson plan dengan memperhatikan kejelasan langkah saintifik yang disusun, kesesuaian aktivitas guru dan siswa dalam rencana pembelajaran serta penjelasan media yang akan digunakan dalam lesson plan yang disusun.

Selain lesson plan, perangkat pembelajaran yang berhasil dirancang oleh guru dalam workshop adalah lembar observasi yang akan digunakan untuk mengamati aktivitas guru dan siswa pada saat implementasi lesson study di masing-masing kelompok oleh guru model. Lembar observasi merupakan salah satu perangkat pembelajaran yang penting karena digunakan sebagai alat pengumpul data proses pembelajaran dan digunakan saat sesi refleksi dalam lesson study. Melalui lembar observasi, keterampilan siswa dan kinerja guru dalam proses pembelajaran dapat diamati bahkan dinilai (Hertiavi dkk, 2010). Lembar observasi yang disusun guru saat sesi pelatihan juga didasarkan pada langkah-langkah pembelajaran yang disusun sehingga aktivitas siswa dan aktivitas guru dapat dideskripsikan melalui lembar observasi. 


\section{Tahap Evaluasi Pelatihan}

Sebelum kegiatan berakhir, seluruh peserta diberikan tes akhir (post-test) untuk mengetahui tingkat pemahaman guru terhadap materi yang telah disampaikan selama sesi pelatihan. Tes yang diberikan dalam bentuk tes tertulis dengan indikator yang sama seperti tes. Kemudian setelah kegiatan tes akhir, para guru bersama Tim Pengabdi merencanakan jadwal kegiatan lanjutan berupa workshop dan pelatihan media, bahan ajar serta asessment dalam pembelajaran IPA. Pada kegiatan akhir juga ditentukan guru model yang akan melaksanakan implementasi lesson study (open class) pada masing-masing kelompok.

Tabel 1. Data Kehadiran Guru dalam Kegiatan Wokshop

\begin{tabular}{clc}
\hline No & \multicolumn{1}{c}{ Kecamatan } & Guru hadir \\
\hline 1 & Sungai Ambawang & 7 \\
\hline 2 & Kuala Mandor B & 2 \\
\hline 3 & Sungai Kakap & 9 \\
\hline 4 & Sungai Raya & 18 \\
\hline 5 & Rasau Jaya & 5 \\
\hline 6 & Batu Ampar & 2 \\
\hline 7 & Kubu & 3 \\
\hline 8 & Terentang & 2 \\
\hline \multicolumn{2}{c}{ Total Guru yang Hadir } & $\mathbf{4 8}$ \\
\hline
\end{tabular}

Berdasarkan daftar hadir peserta workshop (Tabel 1), diketahui bahwa jumlah peserta guru yang hadir sebanyak 48 orang atau sebanyak $92,30 \%$ dari 52 guru anggota MGMP yang diundang. Hal tersebut merupakan salah satu indikator bahwa para guru antusias dalam menghadiri kegaiatan workshop yang dilaksanakan. Ini merupakan suatu keberhasilan dalam memotivasi para guru untuk mengikuti berbagai kegiatan peningkatan kualitas pembelajaran. Keberhasilan tersebut juga didasarkan bahwa daerah tempat tinggal para guru yang relatif jauh dari lokasi kegiatan yang tersebar pada berbagai kecamatan. Beberapa guru yang hadir berasal dari daerah jauh dari lokasi kegiatang wokshop.

Beberapa kecamatan seperti Kecamatan Batu Ampar dan kecamatan Kubu berjarak kurang lebih $50 \mathrm{~km}$. Bahkan kegiatan workshop dihadiri oleh guru dari daerah terjauh yaitu Kecamatan Terentang yang berjarak kurang lebih $80 \mathrm{~km}$ serta mlintasi jalur perairan. Namun para guru antusias menghadiri kegiatan PKM yang dilasanakan oleh Tim Pengabdi.
Tabel 2. Hasil Pre Test dan Post Test Peserta Workshop

\begin{tabular}{lcc}
\hline \multirow{2}{*}{ Kategori Nilai } & \multicolumn{2}{c}{ Jumlah Peserta } \\
\cline { 2 - 3 } & Pre Test & Post Test \\
\hline Sangat Baik & 2 & 25 \\
\hline Baik & 7 & 13 \\
\hline Cukup & 28 & 2 \\
\hline Kurang & 11 & 1 \\
\hline Jumlah Peserta & $\mathbf{4 8}$ & $\mathbf{4 1}$ \\
\hline
\end{tabular}

Tabel 3. Skor dan Kriteria Peningkatan Hasil Tes

\begin{tabular}{ccc}
\hline Skor Peningatan & Kriteria & $\begin{array}{c}\text { Jml } \\
\text { Peserta }\end{array}$ \\
\hline N-Gain $\geq 0,7$ & Tinggi & 5 \\
\hline $0,7>$ N-Gain $\geq 0,3$ & Sedang & 31 \\
\hline $0,3>$ N-Gain & Rendah & 5 \\
\hline Selain & antusias & kehadiran,
\end{tabular}

kebermanfaatan program juga dilihat dari meningkatnya pemahaman guru pada materi yang disampaikan dalam kegiatan workshop. Data hasil tes awal dan tes akhir ditampilkan pada Tabel 2. Tes akhir hanya diikuti oleh 41 dari 48 orang guru yang hadir, dikarenakan 7 orang guru yang berasal dari Kecamatan Batu Ampar, Kecamatan Kubu dan Kecamatan Terentang meminta izin untuk pulang lebih awal dan tidak mengikuti sesi penutupan dan tes akhir. Kategori nilai pretest dan post test (Tabel 2) menggunakan kriteria tes kegiatan pengabdian yang dikemukakan oleh Pratiwi (2017). Skor peningkatan (gain) pemahaman dan kriteria peningkatan hasil tes guru (Tabel 3) dihitung menggunakan Persamaan Gain Ternormalisasi (N-Gain) oleh Hake (1998). Hasil tes menunjukkan bahwa pada saat tes awal $28 \quad(58,33 \%)$ guru memahami perencanaan pembelajaran dengan kategori yang cukup bahkan $11(22,92 \%)$ guru berada pada kategori yang kurang.

Namun setelah peserta diberikan materi tentang perencanaan pembelajaran maka terdapat $25(52,08 \%)$ guru telah memiliki kriteria pemahaman yang sangat baik. Hal tersebut menunjukkan adanya peningkatan pemahanan guru setelah diberikan materi tentang perencanaan pembelajaran khususnya materi tahapan penyusunan rencana pembelajaran, prinsip penyusunan rencanan pembelajaran, pengembangan indikator pembelajaran dan esensi langkah-langkah pembelajaran dalam rencana pembelajaran. Persentase guru yang memiliki peningkatan pemahaman kategori tinggi sebesar 12,19\% (5 orang) dan sebagian besar $(75,61 \%$ atau 31 dari 4 orang) memiliki peningkatan 
pemahaman yang sedang tentang perencanaan pembelajaran. Hasil ini menunjukkan bahwa materi workshop dan pelatihan dapat dipahami dengan baik oleh para guru sebagai peserta workshop.

\section{KESIMPULAN \& SARAN}

Kesimpulan dari kegiatan pengabdian Program Kemitraan Masyarakat (PKM) ini adalah: (1) Guru antusias menghadiri kegiatan workshop yang dilaksanakan oleh Tim Pengabdi dengan persentase kehadiran sebesar $92,30 \%$ atau melebihi target minimal kehadiran $80 \%$, (2) pemahaman guru mengenai perencanaan pembelajaan meningkat dan sebagian besar berada pada kategori yang sangat baik $(52,08 \%)$ setelah materi workshop dan pelatihan disampaikan, (3) guru memiliki keterampilan dalam membuat lesson plan dan perangkat pembelajaran berupa lembar observasi pada mata pelajaran IPA materi Fisika, Kimia dan Biologi yang akan digunakan dalam kegiatan lesson study. Saran kegiatan pengabdian ini adalah perlumya dilakukan kegiatan lanjutan serupa untuk mengembangkan lesson plan dan lembar observasi secara lengkap sehingga dapat dijadikan pedoman bagi guru dalam mengimplementasikan lesson study sebagai sebuah learning community.

\section{UCAPAN TERIMA KASIH}

Kegiatan pengabdian pada masyarakat ini dibiayai oleh Ditjen Penguatan Riset dan Pengembangan Kementerian Riset, Teknologi, dan Pendidikan Tinggi melalui dana Program Kemitraan Masyarakat (PKM). Untuk itu diucapkan terima kasih yang sebesar-besarnya sehingga kegiatan pengabdian ini dapat dilaksanakan dengan baik dan lancar oleh Tim Pengabdi IKIP PGRI Pontianak.

\section{DAFTAR PUSTAKA}

Bertsch, C., Kapelari, S., \& Unterbruner, U. (2014). From cookbook experiments to inquiry based primary science: influence of inquiry based lessons on interest and conceptual understanding. Inquiry in primary science education (IPSE), 1, 2031 .

Hake, R.R. (1998). Interactive-engagement vs traditional methods: a six-thousandstudent survey of mechamics test data for introductory physics courses. American Journal of Physics, 66(1), 64-74.
Hertiavi, M. D., Langlang, H., \& Khanafiyah, S. (2010). Penerapan model pembelajaran kooperatif tipe jigsaw untuk peningkatan kemampuan pemecahan masalah siswa SMP. Jurnal Pendidikan Fisika Indonesia, 6(1), 53-57.

Hosnan, M. (2014). Pendekatan Saintifik dan Kontekstual dalam Pembelajaran Abad 21: Kunci Sukses Implementasi Kurikulum 2013. Jakarta: Ghalia Indonesia.

Mania, S.(2008). Observasi sebeagai Alat Evaluasi dalam Dunia Pendidikan dan Pengajaran. Lentera Pendidikan, 11(2), 220-233.

Murtiani, M., Fauzan, A., \& Ratnawulan, R. (2012). Penerapan Pendekatan Contextual Teaching and Learning (CTL) Berbasis Lesson study dalam Meningkatkan Kualitas Pembelajaran Fisika di SMP Negeri Kota Padang. Jurnal Penelitian Pembelajaran Fisika, 1(1), 1-21.

Mustofa, Z., Susilo, H., \& Al Muhdhar, M. H. I. (2016). Penerapan model pembelajaran problem based learning melalui pendekatan kontekstual berbasis lesson study untuk meningkatkan kemampuan memecahkan masalah dan hasil belajar kognitif siswa SMA. Jurnal Pendidikan: Teori, Penelitian, Dan Pengembangan, 1(5), 885-889.

Pratiwi RD, RH Pratiwi, \& S Noer. (2017). Peningkatan Kompentensi Guru Biologi Melalui Pelatihan Penggunaan Aplikasi Bioinformatika. Qardhul Hasan: Media Pengabdian kepada Masyarakat, 3(2), 153- 160.

Rahayu, P., Mulyani, S., \& Miswadi, S. S. (2012). Pengembangan pembelajaran ipa terpadu Dengan menggunakan model pembelajaran problem base melalui lesson study. Jurnal Pendidikan IPA Indonesia, $1(1), 63-70$.

Subadi, T., \& Hidayati, E. F. (2013). Lesson study sebagai Inovasi Pendidikan. Surakarta: Kafilah Publishing.

Susilo, H., Chotimah, H., Joharmawan, R., Juniati, Sari, D.Y., \& Sunarjo. (2011). Lesson Study berbasis Sekolah: Guru Konservatif Menuju Guru Inovatif. Malang: Bayumedia Publishing.

Susilo, H., Chotimah, H., Sulistyowati, K., Kartini, Ikhsan, M., \& Heringngsih, D.P. (2010). Lesson Study berbasis MGMP sebagai Sarana Pengembangan Keprofesionalan Guru. Malang: Surya Pena Gemilang. 
Winarsih, A., \& Mulyani, S. (2012). Peningkatan profesionalisme guru IPA melalui lesson study dalam pengembangan model pembelajaran PBI. Jurnal Pendidikan IPA Indonesia, 1(1), 43-50. 